\title{
Evaluating of the financial equalization system in Ukraine
}

\section{Sowa Bożena}

$\mathrm{PhD}$, University of Law and Public Administration University of Rzeszow, Faculty of Public Administration, Management and Business, Poland.

Natalia Vynnychenko

$\mathrm{PhD}$, Associate professor, Accounting and Taxation Department, Sumy State University, Ukraine.

\begin{abstract}
The article assesses the effectiveness of the functioning of the financial equalization system in Ukraine. The authors of the article developed the indicator of the level of efficiency of the equilibrium procedures, calculated on the basis of the ratio of Gini coefficients to the revenues of local budgets with and without intergovernmental transfers. Using the Gini coefficient, the authors quantified the success of the financial equalization mechanism.
\end{abstract}

Key words: financial equalization system, Gini coefficient, local budget.

JEL Classification: G2, G28, G41.

(C) The Authors, 2018. This article is published with open access at Sumy State University.

\section{Introduction}

For the last three decades, academics are often called the "era of financial decentralization", because it is precisely the implementation of this concept of state regulation of the economy that focuses on the authorities that are authorized to formulate and implement financial (fiscal) policy.

The functioning of the financial equalization system is closely related to the problems of financial decentralization, since the latter aims at correcting the regional development imbalances caused by the lack of financial autonomy of local self-government bodies. The first plans for the implementation of certain aspects of financial equalization by a number of federal countries were implemented as early as the $1940 \mathrm{~s}-1950 \mathrm{~s}$, but the concept was acquired especially during the last two decades (Blochliger $\mathrm{H}$ ), especially in terms of dissemination and qualitative transformation.

Approaches to the financial equalization can vary considerably depending on the peculiarities of the socioeconomic development of a country and its regions, the specifics of the administrative-territorial system, historical preconditions, targets for fiscal and tax policies, and a number of other factors. That is why there is an objective need to determine the main tendencies in the direction of financial equalization that have developed in domestic and world practice, the characteristics of key approaches to its implementation, as well as the formation of models of financial equalization, which will create a unified mechanism for selecting the appropriate algorithm of action of the authorities authorized on realization of fiscal-budgetary policy, which would allow to achieve with maximum efficiency the main task of the process of financial equalization smoothing the region lnyh imbalances and promote sustainable economic development in general.

\section{Literature review and legislative history}

Sometimes researchers give a rather different assessment of the role of financial equalization and intergovernmental transfers in fiscal relations between levels of government. The nature of these contradictions lies in the diversity of target orientations and the final result of financial equalization, as well as differences in determining the role of sub-central governments in fiscal-budgetary policy and ensuring the sustainable development of the state as a whole.

Thus, Andras Vigwari in his research notes that the role of financial decentralization and the need for financial equalization can be characterized from two different positions. According to the first approach, which in the scientific literature is called the Tibu-Outs paradigm, the main goal of decentralization is adequate provision of public services at the local level, with the important task of achieving such a level of taxation and expenditures from the local budget that fully corresponds to the preferences of a particular territorial community. In turn, consumers of public goods can show their loyalty at the expense of migration between cities. Thus, within the framework of this approach, financial decentralization is aimed at unique remediation measures, that is, the elimination of uncompetitive territorial communities in favor of those who are able to provide a high level of quality of provision of public services for an acceptable tax burden. In turn, the second 
approach involves the definition of the role of decentralization as a mechanism that ensures the provision of public services within the administrative units of the country at the optimum level by forming the size of the territorial communities taking into account economic efficiency, targeting the process of providing public services, reducing transaction costs, etc. It is within this framework that the design of the system of financial equalization, the typology of grants from the state budget and their intended purpose play an important role. The current stage of development of economic relations, an effective system of financial equalization is one of the most important supporting mechanisms of the effectiveness of measures within the framework of financial decentralization, whose task in this process is not just the redistribution of financial resources between different levels of government, but the construction of such a mechanism for the mobilization of funds, which simultaneously stimulated territorial communities to increase their own financial base and, at the same time, supported those regions that are from the object inthem reasons are not able to self-finance their spending authority. H. Blokhler, one of the world's leading experts in the field of financial decentralization and financial equalization, identifies financial equalization as a redistribution of financial resources between administrative and territorial entities, with the aim of smoothing out the differences in the level of possibilities for expanding the sources of budget revenue generation or the availability of funds to finance public goods. The main task of financial equalization is to achieve such a state of development of financial relations at the local level, in which local governments throughout the country will be able to provide residents of the respective territorial community with a similar set of public goods at a similar level of tax burden. At the same time, regions with low tax potential, but high level of population provision with public services, and those with high potential for increasing the local budget revenue base, but low level of public goods supply to members of the territorial community, are equally ineffective. Thus, the task of financial equalization is to find a balance between the problem of accrual of incomes and the implementation of expenditures at such a scale that would be available to all administrative units of the country. So, before moving on to assess the effectiveness of the functioning of the financial equalization system in Ukraine at the present stage of development, it is advisable to analyze its genesis in order to identify the key features of this system, its strengths and weaknesses.

The qualitative transformation of intergovernmental fiscal relations in the direction of enhancing the clarity of the budget process and its transparency took place with the adoption of the first edition of the Budget Code of Ukraine (Budget Code of Ukraine: Law of Ukraine No. 2542-14 of 21.06.2001), which came into force on July 24, 2001. Adoption of the Budget the Code of Ukraine became an important step not only in the process of establishing a system of financial equalization (in this document the whole chapter was devoted to intergovernmental transfers), but also to improve the efficiency of the functioning of the budget system as a whole since most of the important issues regarding the organization of budget relations have now been collected in a single legislative act. However, despite the fact that Chapter 16 of the Budget Code of Ukraine was devoted to the characterization of types of intergovernmental transfers (equalization subsidies and subventions), as well as the order of their allocation, it did not contain detailed instructions on the application of the formula approach, which was implemented with the adoption of the Budget Code. This problem was partially resolved on 05.09.2001, when the Cabinet of Ministers of Ukraine adopted the Resolution No. 1195 "On Approval of the Formula for the Distribution of Intergovernmental Transfers (Equalization Grants and Funds Transmitted to the State Budget) between the State Budget and Local Budgets" (Approval Formula for the distribution of intergovernmental transfers), but since then, the procedural aspects of financial equalization have been enshrined in several regulatory documents, which has led to a number of inconveniences for participants in the budget. However, it is fair to note that the adoption of the Budget Code of Ukraine and the implementation of the formulaic approach to financial equalization can be considered as the most significant transformations in this sector in the history of independent Ukraine, which has greatly brought our state closer to the formation of intergovernmental relations on a transparent and democratic basis.

The Resolution of the Cabinet of Ministers of Ukraine No. 1195 "On Approval of the Formula for the Distribution of Intergovernmental Budget Transfers (Equalization Grants and Funds Transmitted to the State Budget) between the State Budget and Local Budgets" provided for the determination of the number of subsidies based on a formula that in aggregated form was the difference between the assigned revenues and expenses for the financing of delegated powers. It should be noted that a number of forecast macroeconomic indicators were taken into account when calculating income, and the volume of expenditures was determined by a separate formula for each group using a number of statistical indicators and correction factors. Thus, the formula for calculating the equalization subsidies was very complex and cumbersome, and during the period of its existence (from 05.09.2001 until the date of expiration on January 1, 2011) 20 editors suffered (2001 3 editions, $2002-1,2003-2,2004-3,2005-3,2006-2,2007-3,2008-2,2009-1,2010-1)$. It is logical that the complexity of the formula approach, the plurality of normative documents regulating financial 
equalization, as well as instability of the normative field significantly reduced the effectiveness of this process, which actualized the need for its further transformation, simplification and unification in a single legislative act. The Resolution of the Cabinet of Ministers of Ukraine No. 1195 "On Approval of the Formula for the Distribution of Intergovernmental Budget Transfers (Equalization Grants and Funds Transmitted to the State Budget) between the State Budget and Local Bodies" expired on the basis of the Resolution of the Cabinet of Ministers of Ukraine No. 1149 "Some Issues of the Distribution of Intergovernmental Fiscal Transfers" Dated December 8, 2010. In fact, the same document consolidated a new version of the formula for calculating the amount of equalization grants and reverse subsidies. However, this resolution was also not characterized by significant stability: since the entry into force of 01.01.2011 and until the effective date of 11.02 .20158 editors were adopted, 4 of which in 2011. Loss of the Decree of the Cabinet of Ministers of Ukraine No. 1195 "On Approval of the Formula for the Distribution of Intergovernmental Transfers (Equalization Grants and Funds Transmitted to the State Budget) between the State Budget and Local Budgets" as of 01.01.2011 was accompanied by a fundamental transformation of the Budget Code of Ukraine, a new variant (with amendments and additions valid and to date) which was adopted on July 8, 2010, but it came into force from the very beginning of the new fiscal year. At the same time, the decree of the Cabinet of Ministers of Ukraine No. 1149 "Some Issues of the Distribution of Intergovernmental Fiscal Transfers" of February 11, 2015 and amendments to the Budget Code of Ukraine (based on the Law of Ukraine "On Amendments to the Budget Code of Ukraine on the Reform of Intergovernmental Fiscal Relations" No. 79-19 of 01.01.2015) marked the beginning of a new, modern stage of the functioning of the financial equalization system, which is characterized by a waiver of the formula approach, the transition to a horizontal equalization of incomes (not fixed expenditure capacity of local budgets) and synthesis study legislation in the field - all questions regarding the mechanism of financial compensation stipulated in the Budget Code of Ukraine. At the same time, for this stage, the alignment of the system of financial equalization to the needs of the newly formed united territorial communities is characteristic, because of the decentralization of power in Ukraine. The key issues of the reform are enshrined in the Law of Ukraine "On Voluntary Association of Territorial Communities", the Seventh Edition of this Law (amendments since 16.04.2017) is in force, but at the end of the year, changes are planned for both this normative document and to the Budget Code of Ukraine.

In the new version of the Budget Code of Ukraine, the mechanism for implementing intergovernmental transfers is described in Chapter 16. In accordance with the Budget Code, intergovernmental transfers may take the form of basic grants, reverse grants, additional subsidies and various subventions (educational, medical, on implementation of state social protection programs, implementation of investment projects etc.). It should be noted that the basic and reverse grants reflect different directions of financial flows in the course of equalization of incomes, whereas subventions - provide for the allocation of additional financial resources to cover the costs associated with the implementation of national functions (social protection, education, health etc.), that is, an element of equalization of expenditures, although the de jure existence of this mechanism in our state is not fixed.

Ukraine has legislated only the implementation of a horizontal equalization of the fiscal capacity of local budgets (during the period of the formula approach to financial equalization, smoothing was subjected to both imbalances in the formation of the revenue base of budgets, and their expenditure load). The basis of equalization of tax capacity of regional budgets is the income from personal income tax (PIT) and corporate income tax; budgets of cities of oblast significance, united territorial communities and rayon budgets only the income from the personal income tax. The base of the equalization and the population of the corresponding territory, the calculation of the tax capacity index of a specific budget is made; comparing the value of the calculated indicator with a similar averaged indicator in the country is the basis for determining the amount of the subsidy. So, in the case when the calculated indicator is within the range of 0.9-1.1 from the average for the country, there is no equalization; if the tax capacity index of a particular budget is less than 0.9 from the country average - a basic grant is provided, which is $80 \%$ of the amount required to reach the target budget of the target value of 0.9 ; if the index of fiscal capacity exceeds the value of $1.1-$ a reverse grant is transferred, in the amount of 50\% of the excess amount exceeding 1.1 (Budget Code of Ukraine: Law of Ukraine No. 245617 dated 08.07.2010). Thus, the current system of financial equalization in Ukraine is much simpler, compared to the period of functioning of the formula approach, but it is not devoid of certain shortcomings. In particular, a rather controversial step is the waiving of equalization of expenditures (there is a latent smoothing mechanism through the provision of a number of subventions, but the algorithm for determining their amount remains non-transparent). Thus, the Budget Code stipulates that the volume of subventions is set by the Cabinet of Ministers of Ukraine, but this process depends to a large extent on planned state budget indicators and fiscal policy vectors, which makes it not sufficiently objective and scientifically substantiated. In addition, in our 
country there is still no legislative mechanism to calculate the financial standard of the cost of a standard set of public services per inhabitant. Considering all of the above, there is an objective need to assess the effectiveness of the functioning of the domestic financial equalization system, to analyze the experience of the leading countries of the world and to develop, on its basis, conceptual foundations for improving the intergovernmental fiscal relations in Ukraine.

The evolution of the financial equalization system in Ukraine is presented in Figure 1.

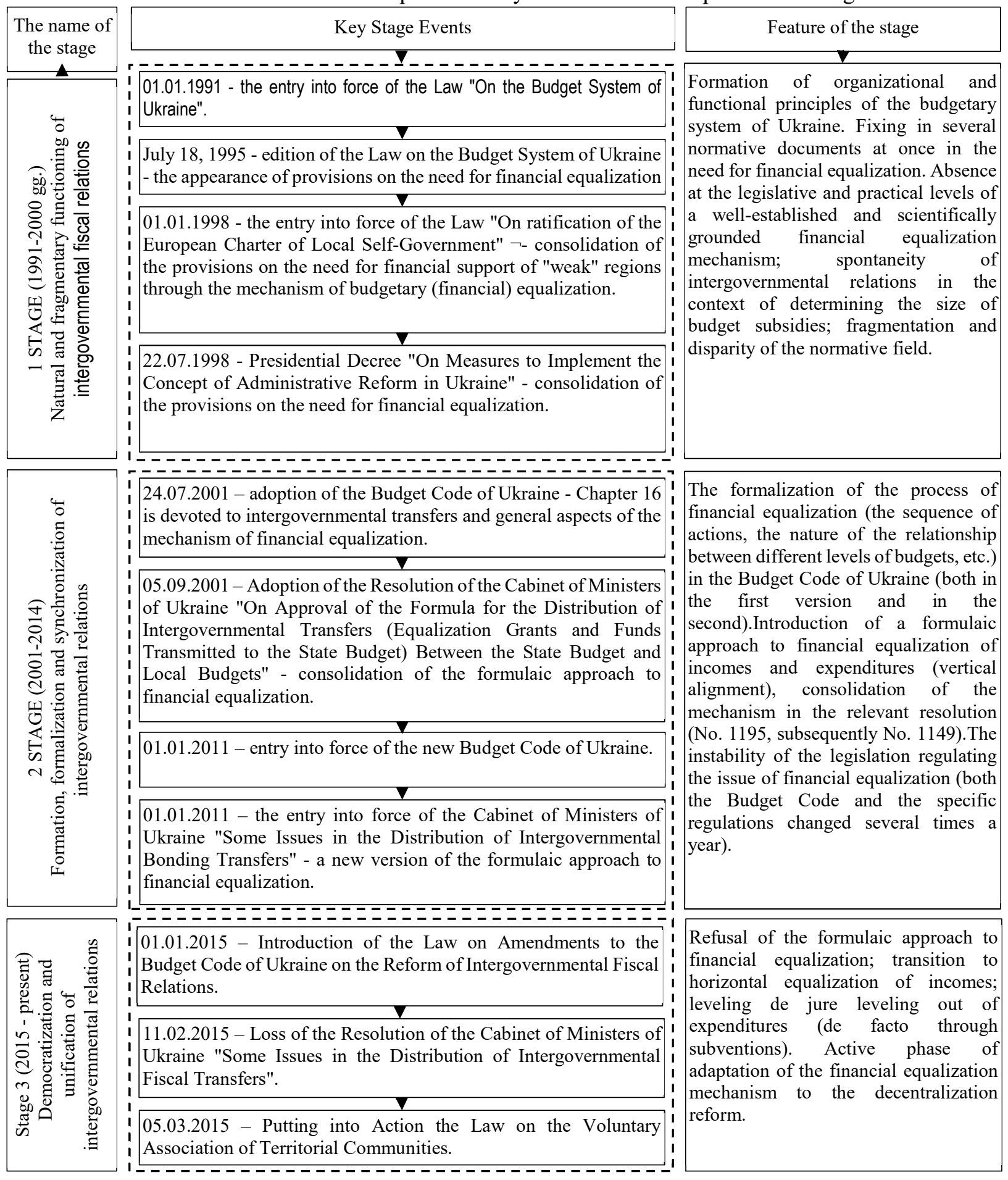

Figure 1. Stages of the formation of a financial equalization system in Ukraine (compiled by the author)

It is necessary to determine a specific quantitatively measurable indicator that would allow to assess the effectiveness of measures under the financial equalization. As already mentioned, one of the main tasks of the financial equalization process is to smooth out regional imbalances, and therefore the required indicator should reflect the progress of the authorized state authorities in solving the task. One of the leading OECD financial equalization experts - H. Blokhler, in his research (Blochliger H. Fiscal Equalization - a Cross-Country 
Perspective) as a benchmark for the efficiency of the equilibrium procedures, mentions several parameters: the ratio between the highest and the lowest rates of ability to pay before and after equalization, as well as the Gini coefficient before and after equalization, calculated on the basis of the level of solvency of subational entities. Of the two indicators given below, the Gini coefficient is more substantiated and meaningful, since this calculated indicator in statistics is one of the most visible parameters that characterize the degree of distribution concentration.

However, from our point of view, it is debatable to calculate the Gini coefficient on the basis of the budget capacity indicator, since the approach to defining this indicator varies considerably in countries of the world: as a rule, the degree of fiscal capacity is determined on the basis of a representative tax system, which includes non-local taxes and fees, and national ones, which are subject to redistribution from the budget of a higher level, and their list can vary considerably. Thus, the local sources of local budgets are out of sight. In addition, a representative tax system in some cases is an abstract concept that does not have a close relationship with the amount of real revenues of the relevant budget.

\section{Methods and results}

The evaluation of the effectiveness of financial equalization will be carried out for the regions of Ukraine for the period of 2008-2016. The changes in the administrative and territorial structure of Ukraine during the investigated time range, to level the probability of distortion of the obtained results and comparability of the sample size throughout the observation period, 25 regions of Ukraine (24 administrative regions and Kyiv) were selected.

Calculation of the Gini coefficient in the framework of this study will be carried out by the formula 1:

$$
K_{G}=1-2 \sum x_{i} \text { Cumy }_{i}+\sum x_{i} y_{i},
$$

$K_{G}$ - the value of the Gini coefficient;

$x_{\mathrm{i}}$-the share of distribution by the number of elements of the population (taking into account the number of regions -25 , and their equivalence, this value is fixed and is $100 / 25=4 \%$ );

$y_{\mathrm{i}}$ - share of the distribution by value of the sign (specific gravity of income per capita and region in the total amount of the indicator);

Cum $y_{\mathrm{i}}$ - the cumulative share of the distribution in terms of the values of the sign.

The information base of the study is official statistics broken down by regions of Ukraine, namely: indicators of implementation of local budget revenues with and without intergovernmental transfers - information from the Ministry of Finance of Ukraine (Statistical collection "Budget of Ukraine" for 2012-2016); the number of available population (needed to calculate the volume of local budget revenues per capita) - information from the State Statistics Service of Ukraine.

The analysis of the data presented in the Appendix (Appendix A, B, C, D) allows us to draw the following conclusions: the Gini coefficient calculated on the basis of local budget revenues, excluding intergovernmental transfers, shows the relatively high degree of uneven distribution of this group of sources of financial resources in terms of regions Ukraine, which confirms the necessity of applying the financial equalization mechanism; with particular concern, the increase in the Gini coefficient over the last few years (after the transformation of the approach to financial equalization), which may be an indication of the ineffectiveness of the reforms; after the equilibrium procedures, the Gini coefficient decreases significantly (almost tripled), which confirms the existence of a positive effect of financial equalization on the uniformity of the provision of the regions with budget funds (including intergovernmental transfers); in the regions with the lowest revenues of local budgets, taking into account intergovernmental transfers per capita, Lugansk region was constantly included. (led by this list), as well as the Kharkiv region often appeared (it was in three outsiders 5 times), Sumy region (3 times), Lviv and Donetsk regions (2 times); the most secured per capita after the distribution of intergovernmental transfers were found in Kyiv, Volyn region (it was in the top three of the leaders 5 times), Rivne region (5 times), Kyiv region (3 times, consolidated during 2015-2016) and Donetsk region (2 times); as a measure of the equilibrium effect, the indicator calculated according to the formula 2 is proposed:

$$
E f=\left(1-K_{G 1} / K_{G 2}\right) \times 100
$$

where $E f-$ level of equilibrium effect, \%; 
$K_{G 1}$ - the value of the Gini coefficient, calculated on the basis of the volume of local budget revenues, taking into account intergovernmental transfers per capita; $K_{G 2}-$ the Gini coefficient, calculated on the basis of local budget revenues, excluding intergovernmental transfers per capita.

Thus, the indicated indicator allows quantifying the success of the functioning of the financial equalization mechanism, since the value of the indicator is approaching $100 \%$ in the case when the Gini coefficient calculated on the basis of local budget revenues, taking into account intergovernmental transfers per capita, goes to zero (that is, the main objective of financial equalization is almost completely realized - the leveling of regional imbalances in the provision of financial resources).According to Fig. 2 the equilibrium effect was relatively high and was in the range of $70-80 \%$, while with the change of the mechanism of financial equalization in Ukraine the value of the investigated indicator is rapidly decreasing, and in 2016 The efficiency of the equalization procedures barely exceeded $50 \%$, which indicates the low effectiveness of the modern approach and the need for its revision and improvement in the light of best world practices in this area. At the same time, quite often, the low efficiency of the functioning of the financial equalization mechanism is due not only to the internal deficiencies of the system itself, but also to the negative influence of external factors, and therefore there is an objective need for a more in-depth study of the mentioned problem in the context of identifying the parameters that have the most significant impact on the level of efficiency of equalization procedures in Ukraine.

The implementation of the task is proposed to be carried out using the tools of regression analysis of the software complex Stata 12 / SE. The observation period covers the time range 2015-2016. The effective variable serves, calculated by the formula 2, the level of equivalence effect, the list and characteristics of the factor variables are given in Table. 1. In particular, the set of independent variables of the model proposes to include indicators that reflect: 1) the state of investment attractiveness (FDI) and investment activity of business entities (gross accumulation of capital and gross fixed capital accumulation), since the efficiency of the country in the direction attraction of financial resources from external sources may reduce the need to find sources of financing for a number of important projects in the domestic capital market, which, in turn, may be partly solved. you issue insufficiency of financial resources and the need for transfers from the state budget to implement these initiatives; 2) the level of entrepreneurial activity (the cost of starting a business, the number of enterprises, the volume of sales) - like investment activity, the intensity of entrepreneurial activity can positively affect the expenditure burden on the budget and the amount of transfers in the framework of financial equalization; 3) export activity (balance of current operations, level of openness of the economy); 4) characteristics of labor efficiency (average monthly wages and unemployment), etc.

Table 1. Characteristics of independent variables of regression analysis for determining the impact on the efficiency of equivalence procedures in Ukraine

\begin{tabular}{|l|c|c|}
\hline Indicator marker & Characteristic of the indicator & Source \\
\hline FDI & Volume of direct foreign investments, USD USA & World Bank [23] \\
\hline CoB & Cost of starting a business, \% GNI per capita & World Bank [23] \\
\hline CAB & Current account balance, \% of GDP & World Bank [23] \\
\hline GCF & Gross capital accumulation, \% of GDP & World Bank [23] \\
\hline GFCF & Gross fixed capital accumulation, \% of GDP & World Bank [23] \\
\hline Trade & The level of openness of the economy (the ratio of the total volume of & World Bank [23] \\
\hline TTR & Total tax burden on business (share of taxes on corporate profits) & World Bank [23] \\
\hline Res & General reserves, including gold dollars USA & $\begin{array}{c}\text { State Statistics Service of } \\
\text { Ukraine [24] }\end{array}$ \\
\hline Unempl & Share of the unemployed among the population aged 15-70 years \\
(according to the ILO methodology), \% & $\begin{array}{c}\text { State Statistics Service of } \\
\text { Ukraine [26] }\end{array}$ \\
\hline Enterpr & Number of enterprises, units. & $\begin{array}{c}\text { State Statistics Service of } \\
\text { Ukraine [27] }\end{array}$ \\
\hline Turnover & Volume of sales of products (goods, services) by enterprises of the \\
& country, UAH million. & $\begin{array}{c}\text { State Statistics Service of } \\
\text { Ukraine [28] }\end{array}$ \\
\hline CPI & Consumer price index (December to December of the previous year), \% \\
\hline
\end{tabular}

Testing for the relationship between the level of efficiency of the equilibrium procedures and each of the tables in the table. 1 variables (single-factor regression modeling), allowed to divide the above parameters into three groups: statistically significant (on one of the confidence intervals $99 \%, 95 \%$ or $90 \%$ ) factors of positive 
influence (Table 2); statistically significant factors of negative influence (Table 3); statistically insignificant factors.

So, according to the Table 2 it can be noted that the increase of the tax burden on business positively affects the effectiveness of financial equalization, which is quite natural, since it is tax revenues to the state budget are the main source of payment of transfers, and therefore, the more financial resources are at the disposal of authorized state authorities, the greater their volume can be directed at smoothing regional imbalances.

Table 2. Results of regression modeling to find out the relationship between factors and the level of efficiency of equilibrium procedures (a group of statistically significant factors of positive influence)

\begin{tabular}{|l|c|c|c|c|c|}
\hline \multicolumn{1}{|c|}{ Marker factor } & $\begin{array}{c}\text { The value of the } \\
\text { coefficient }\end{array}$ & $\begin{array}{c}\text { Standard } \\
\text { deviation }\end{array}$ & $\mathrm{t}$ & $\mathrm{P}>|\mathrm{t}|$ & $\mathrm{R}^{2}$ \\
\hline TTR & 3.1278 & 1.0356 & 3.02 & 0.019 & 0.57 \\
\hline Res & $6.41 \mathrm{e}-10$ & $2.33 \mathrm{e}-10$ & 2.76 & 0.028 & 0.52 \\
\hline GCF & 1.0972 & 0.5026 & 1.88 & 0.100 & 0.34 \\
\hline
\end{tabular}

Insignificant in scope, but statistically significant positive effect on the efficiency of the equilibrium procedures has an increase in total reserves, which can be explained as follows: the increase of the analyzed indicator usually occurs during periods of positive dynamics of the economic cycle, and in such periods, as a rule, the gap of regional disproportions is reduced, which in other equal conditions, automatically increases the efficiency of financial equalization. Finally, given the fact that the gross accumulation of capital involves the accumulation of assets by economic agents, the use of which will generate additional profits, the positive effect of this indicator on financial equalization is quite logical, since capital is not concentrated in one entity, but through the financial market redistributed between economic agents (donors and recipients). Thus, an increase in capital in various forms of assets, firstly, indicates a favorable economic situation, which is accompanied by a high probability of improving the financial position of local self-government bodies; second, the allocation of capital through the financial market leads to a reduction in the disproportion of financial support for the development of administrative-territorial entities (economic agents have access to financial assets, including financial and financial resources, irrespective of where they originally were accumulated geographically). Consequently, both of these patterns, manifested as a result of an increase in the accumulation of capital, lead to a gradual leveling of the problems that give rise to the need for a system of financial equalization.

Table 3. Results of regression modeling to detect the relationship between factors and the level of efficiency of equilibrium procedures (a group of statistically significant negative factors)

\begin{tabular}{|l|c|c|c|c|c|}
\hline \multicolumn{1}{|c|}{ Marker factor } & The value of the coefficient & Standard deviation & $\mathrm{t}$ & $\mathrm{P}>|\mathrm{t}|$ & $\mathrm{R}^{2}$ \\
\hline CoB & -2.1186 & 1.0496 & -2.02 & 0.083 & 0.37 \\
\hline Turnover & $-5.25 \mathrm{e}-0.6$ & $1.87 \mathrm{e}-06$ & -2.81 & 0.026 & 0.53 \\
\hline Wage & -0.0063 & 0.0019 & -3.21 & 0.015 & 0.60 \\
\hline Unempl & -5.6137 & 2.6560 & -2.11 & 0.072 & 0.40 \\
\hline CPI & -0.4003 & 0.1927 & -2.08 & 0.076 & 0.38 \\
\hline
\end{tabular}

The most statistically significant factors of negative influence on the efficiency of the equilibrium procedures are the growth of the average monthly wage and the volume of sales of products (goods, services) by enterprises of the country. Such an effect of both factors can be explained as follows: higher wages and activation of business activity tend to occur in progressive rather than depressed regions, that is, with a high degree of probability it can be argued that the growth of these parameters in the whole country was not due to due to depressed regions, and especially due to more developed territories (the opposite tendency can be only if large-scale financial support or application of other regulatory instruments for stimulating development tive depressive regions). In turn, the intensification of these processes exacerbates regional imbalances, and, accordingly, complicates the process of financial equalization, leads to an increase in equilibrium payments, which in a chronic deficit of financial resources negatively affects the efficiency of the entire equalization process. The most statistically significant factors of negative influence on the efficiency of the equilibrium procedures are the growth of the average monthly wage and the volume of sales of products (goods, services) by enterprises of the country. Such an effect of both factors can be explained as follows: higher wages and activation of business activity tend to occur in progressive rather than depressed regions, that is, with a high degree of probability it can be argued that the growth of these parameters in the whole country was not due to due to depressed regions, and especially due to more developed territories (the opposite tendency can be only if large-scale financial support or application of other regulatory instruments for stimulating development tive 
depressive regions). In turn, the intensification of these processes exacerbates regional imbalances, and, accordingly, complicates the process of financial equalization, leads to an increase in equilibrium payments, which in a chronic deficit of financial resources negatively affects the efficiency of the entire equalization process.

Similarly, to previous indicators, the negative impact of unemployment growth on the effectiveness of financial equalization may be manifested in the fact that with an increase in this indicator in the country as a whole, the problem will be aggravated in depressed regions (which, as a rule, are the largest recipients of intergovernmental transfers), while For other territories, the destructive effect will be moderate. Thus, rising unemployment will aggravate the problem of uneven development and financial provision of territories, and, as a result, will cause an additional burden on the financial equalization system. The negative effect of inflation growth on the success of financial equalization manifests itself in reducing the real cost of transfers over time, namely: the amount of budget subsidies to local budgets is approved together with the adoption of the law of Ukraine on the state budget for the relevant year, and therefore, in the conditions of rapid price growth, the real value of transfers during budget year is significantly reduced, which worsens the effect of equilibrium procedures. In addition, high inflation worsens the overall efficiency of the functioning of the economic system of any region, which, in conditions of inaccurate inflation forecasting in the process of formation and approval of the state budget, further reduces the effect of intergovernmental transfers: at the end of the budget period, regions may need more than planned at the beginning the sum of the equalization subsidies, which, taking into account the decrease in the real value of these financial resources, leads to a negative synergistic effect for the equilibrium iynyh procedures. The rest of the factors listed in the table. 1, the influence of which is not described above, fell into a group of statistically insignificant factor factors, ie their influence on the efficiency of the equilibrium procedures has not been proved, and therefore their inclusion in the process of reforming the financial equalization system is not feasible.

\section{Conclusion}

Thus, summing up the foregoing, it can be noted that during the period of independence in Ukraine there was a gradual transformation of approaches to financial equalization: from the fragmentation of intergovernmental fiscal relations to their democratization and synchronization with the experience of the leading countries of the world at the present stage of development, but even under these conditions, the mechanism of realization measures of financial equalization has a number of shortcomings that require further elaboration and development of a holistic concept of the transformation of this system with the specification ete APE of its implementation. At the same time, in domestic practice, there are no informative indicators for assessing the effectiveness of these reforms, and therefore developed an indicator of the level of efficiency of the equalization procedures, calculated based on the ratio of the values of the Gini coefficient to the revenues of local budgets with and without intergovernmental transfers. The permanent calculation of this indicator by the central executive body authorized to implement the budget policy will allow monitoring progress in the direction of transformation and improving the efficiency of the financial equalization system. In addition, in the process of elaborating directions for improving equivalence measures, one should not only focus on key indicators of the effectiveness of fiscal policies, but also consider the direction of influence on the efficiency of the equilibrium procedures in a number of other parameters that characterize business activity, the intensity of investment processes, macroeconomic stability, and others.

\section{References}

1. Blochliger H. Fiscal Equalization - a Cross-Country Perspective. Available at :http://www.polsoz.fuberlin.de/polwiss/forschung/systeme/polsystem/Veranstaltungen/Tagung-zur-Reform/ppt-undpaper/Bloechliger.pdf.

2. Blochliger H. (2008). Fiscal Equalization. OECD Economic Studies, 44, 1-22.

3. Blochliger H. Fiscal Equalization in OECD Countries. Available at: https://www.oecd.org/ctp/ federalism/39234016.pdf.

4. OECD Fiscal Decentralisation Database. Available at: http://www.oecd.org/ctp/federalism/ oecdfiscaldecentralisationdatabase.htm\#C Title.

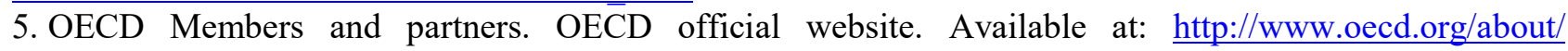
membersandpartners/.

6. Regions at a Glance 2013: OECD report. Official website of OECD library. Available at: http://dx.doi.org/10.1787/reg_glance-2013-en. 
7. Regions at a Glance 2016: OECD report. Official website of OECD library. Available at: http://dx.doi.org/10.1787/reg glance-2016-en.

8. Vigvari A. Lost illusions: fiscal decentralization in Hungary. Available at: http://english.oim.dk/media/14243/andras-vigvari.pdf.

9. Biudzhetnyi kodeks Ukrainy: Zakon Ukrainy № 2456-17 vid 08.07.2010 r. [The Budget Code of Ukraine: Law of Ukraine No. 2456-17 of 08.07.2010]. Available at: http://zakon2.rada.gov.ua/laws/show/ 245617/ed20100708.

10. Biudzhetnyi kodeks Ukrainy: Zakon Ukrainy № 2542-14 vid 21.06.2001 r. [The Budget Code of Ukraine: Law of Ukraine No. 2542-14 of 21.06.2001]. Available at: http://zakon2.rada.gov. ua/laws/show/254214/ed20010621.

11. Deiaki pytannia rozpodilu obsiahu mizhbiudzhetnykh transfertiv: postanova Kabinetu Ministriv Ukrainy № 1149 vid 08.12.2010 r. [Some questions on the distribution of the volume of intergovernmental transfers: the resolution of the Cabinet of Ministers of Ukraine No. 1149 dated 08.12.2010. About the budgetary system of Ukraine: Law of Ukraine № 253/95-vr of July 18, 1995]. Available at: http://zakon2.rada.gov.ua/laws/show/1149-2010-\%D0\%BF.

12. Pro biudzhetnu systemu Ukrainy: Zakon Ukrainy № 253/95-vr vid 18.07.1995 r. [On amendments to the Budget Code of Ukraine on the reform of intergovernmental fiscal relations: Law of Ukraine No. 79-19 of 01.01.2015]. Available at: http://zakon2.rada.gov.ua/laws/show/512-12/ed19950718.

13. Pro vnesennia zmin do Biudzhetnoho kodeksu Ukrainy shchodo reformy mizhbiudzhetnykh vidnosyn: Zakon Ukrainy № 79-19 vid 01.01.2015 r. [On amendments to the Budget Code of Ukraine on the reform of intergovernmental fiscal relations: Law of Ukraine No. 79-19 of 01.01.2015]. Available at: http://zakon2.rada.gov.ua/laws/show/79-19.

14. Pro dobrovilne obiednannia terytorialnykh hromad: Zakon Ukrainy № 157-19 vid 05.02.2015 r. [About voluntary association of territorial communities: Law of Ukraine № 157-19 from 05.02.2015]. Available at: http://zakon3.rada.gov.ua/laws/show/157-19/ed20150205.

15. Pro zatverdzhennia Formuly rozpodilu obsiahu mizhbiudzhetnykh transfertiv (dotatsii vyrivniuvannia ta koshtiv, shcho peredaiutsia do derzhavnoho biudzhetu) mizh derzhavnym biudzhetom ta mistsevymy biudzhetamy: postanova Kabinetu Ministriv Ukrainy № 1195 vid 05.09.2001 r. [On approval of the Formula for the distribution of the amount of intergovernmental transfers (equalization grants and funds transferred to the state budget) between the state budget and local budgets: the resolution of the Cabinet of Ministers of Ukraine No. 1195 dated September 5, 2001]. Available at: http://zakon2.rada.gov.ua/laws/show/1195-2001$\%$ D0\% BF/ed 20070905.

16. Pro zakhody shchodo vprovadzhennia Kontseptsii administratyvnoi reformy v Ukraini: ukaz Prezydenta Ukrainy 810/98 vid 22.07.1998 r. [On Measures to Implement the Concept of Administrative Reform in Ukraine: Presidential Decree 810/98 of 22.07.1998]. Available at: http://zakon2.rada.gov.ua/laws/show/810/98/ ed19980722.

17. Pro ratyfikatsiiu Yevropeiskoi khartii mistsevoho samovriaduvannia : Zakon Ukrainy № 452/97-vr vid 15.07.1997 r. [On ratification of the European Charter of Local Self-Government: Law of Ukraine No. 452/97v of July 15, 1997]. Available at: http://zakon2.rada.gov.ua/laws/show/452/97-\%D0\%B2\%D1\%80.

18. Ukraina: terytorialnyi ohliad [Ukraine: Territorial Review]. Available at: http://old.minregion.gov. ua/attachments/newsattachments/6177/UkraineTerritorialReviewbyOECD_UA.doc.

19. Horoshanska O. O., Prokopova O. V. (2014). Statystyka: osnovy teorii: Navchalnyi posibnyk. TOV «Vydavnytstvo «Fort». [19. Statistics: the basis of theories: a textbook. / OO Horoshanskaya, OV Prokopov / OOO "Vyhodnoe" Fort], Kharkiv, 249.

20. Pokaznyky vykonannia dokhodiv mistsevykh biudzhetiv, shcho vrakhovuiutsia pry vyznachenni obsiahu mizhbiudzhetnykh transfertiv za 2011-2015 rr. Ofitsiinyi sait Ministerstva finansiv Ukrainy. [Indicators of implementation of local budget revenues, which are taken into account in determining the amount of intergovernmental transfers for 2011-2015. Official site of the Ministry of Finance of Ukraine]. Availablee at: http://www.minfin.gov. ua/control/uk/publish/archive/main?\&cat_id=292741\&stind=21.

21. Statystychnyi zbirnyk «Biudzhet Ukrainy» za 2012-2016 rr. Ofitsiinyi sait Ministerstva finansiv Ukrainy [ Statistical collection "Budget of Ukraine" for 2012-2016. Official site of the Ministry of Finance of Ukraine]. Available at: http://www.minfin.gov.ua/news/bjudzhet/poperedni-bjudzheti.

22. Chyselnist naiavnoho naselennia u rozrizi rehioniv Ukrainy za 2008-2016 rr. Ofitsiinyi sait Derzhavnoi sluzhby statystyky Ukrainy. [The number of available population by regions of Ukraine for 2008-2016. Official site of the State Statistics Service of Ukraine.]. Available at: http://www.ukrstat.gov.ua/.

23. The World Bank. Available at: http://www.worldbank.org/. 
24. Riven bezrobittia v Ukraini (za metodolohiieiu MOP) za 2008-2016 rr. Ofitsiinyi sait Derzhavnoi sluzhby statystyky Ukrainy. [The unemployment rate in Ukraine (according to the ILO methodology) for 2008-2016. Official site of the State Statistics Service of Ukraine.]. Available at: http://www.ukrstat.gov.ua/.

25. Serednomisiachna zarobitna plata v Ukraini za 2008-2016 rr. Ofitsiinyi sait Derzhavnoi sluzhby statystyky Ukrainy. [Average monthly wages in Ukraine for 2008-2016. Official site of the State Statistics Service of Ukraine.]. Available at: http://www.ukrstat.gov.ua/.

26. Kilkist pidpryiemstv v Ukraini za 2008-2016 rr. Ofitsiinyi sait Derzhavnoi sluzhby statystyky Ukrainy. [Number of enterprises in Ukraine for 2008-2016. Official site of the State Statistics Service of Ukraine.]. Available at: http://www.ukrstat.gov.ua/.

27. Obsiah realizovanoi produktsii (tovariv, posluh) pidpryiemstvamy Ukrainy za 2008-2016 rr. Ofitsiinyi sait Derzhavnoi sluzhby statystyky Ukrainy. [Volume of sales of goods (goods and services) by enterprises of Ukraine for 2008-2016. Official site of the State Statistics Service of Ukraine]. Available at: http://www. ukrstat.gov.ua/.

28. Indeks spozhyvchykh tsin v Ukraini za 2008-2016 rr. Ofitsiinyi sait Derzhavnoi sluzhby statystyky Ukrainy. [Consumer price index in Ukraine for 2008-2016. Official site of the State Statistics Service of Ukraine]. Available at: http://www.ukrstat.gov.ua/.

29. Clemens J. Federalism and Fiscal Transfers: Essays on Australia, Germany, Switzerland, and the United States. Available at: $\mathrm{http}: / / \mathrm{ssrn} . \mathrm{com} / \mathrm{abstract}=2345398$.

30. German Stability Programme 2017: report of the Federal Ministry of Finance of Germany. Available at : http://www.bundesfinanzministerium.de/Content/EN/Downloads/german-stability-programme-

2017.pdf? blob=publicationFile \& $\mathrm{v}=1$.

31. Kim J. Measuring Fiscal Decentralisation: Concepts and Policies. Available at: http://www.oecdilibrary.org/governance/measuring-fiscal-decentralisation_9789264174849-en.

32. Local government financial equalization 2008. Available at: https://skl.se/download/18.2625f9e6145ac 763d07be205/1401096394 880/Local government financial equalisation SALAR.pdf

33. Barrios S. Fiscal equalization schemes and subcentral government borrowing. Available at: https://www.adb.org/sites/default/files/publication/193181/adbi-wp595.pdf.

34. Carbonell J. Fiscal equalization in Spain. Available at: http://mfile.narotama. ac.id/files/ Economics/Fiscal\%20Federalism\%20and\%20Political\%20 Decentraliza tionChapter $\% 207 \% 20 \%$ 20\%20Fiscal\%20Equalization $\% 20 \operatorname{In} \% 20$ Spain.pdf

\section{Appendix}

Table A.1. Output data for calculating the Gini coefficient based on local budget revenues without intergovernmental transfers in 2011-2016.

\begin{tabular}{|c|c|c|c|c|c|c|c|c|c|c|c|c|}
\hline \multirow[t]{2}{*}{ The region } & \multicolumn{6}{|c|}{ MB revenues per capita, excluding intergovernmental transfers, UAH mln. } & \multicolumn{6}{|c|}{ The share of distribution by the value of the attribute $\left(y_{i}\right), \%$} \\
\hline & 2011 & 2012 & 2013 & 2014 & 2015 & 2016 & 2011 & 2012 & 2013 & 2014 & 2015 & 2016 \\
\hline Ternopil & 0.00097 & 0.00109 & 0.00116 & 0.00126 & 0.00098 & 0.00025 & 2.31 & 2.24 & 2.28 & 2.37 & 1.50 & 1.33 \\
\hline Zakarpattya & 0.00099 & 0.00117 & 0.00127 & 0.00131 & 0.00164 & 0.00045 & 2.38 & 2.40 & 2.48 & 2.47 & 2.53 & 2.39 \\
\hline Chernivtsi & 0.00114 & 0.00128 & 0.00140 & 0.00137 & 0.00166 & 0.00047 & 2.72 & 2.63 & 2.74 & 2.59 & 2.55 & 2.45 \\
\hline Volyn & 0.00116 & 0.00135 & 0.00140 & 0.00147 & 0.00174 & 0.00052 & 2.78 & 2.76 & 2.74 & 2.77 & 2.68 & 2.72 \\
\hline Kherson & 0.00125 & 0.00140 & 0.00142 & 0.00148 & 0.00182 & 0.00052 & 2.99 & 2.86 & 2.78 & 2.80 & 2.80 & 2.73 \\
\hline $\begin{array}{l}\text { Ivano- } \\
\text { Frankivsk }\end{array}$ & 0.00130 & 0.00151 & 0.00155 & 0.00153 & 0.00186 & 0.00053 & 3.10 & 3.08 & 3.03 & 2.88 & 2.86 & 2.78 \\
\hline Rivne & 0.00130 & 0.00152 & 0.00158 & 0.00162 & 0.00190 & 0.00056 & 3.12 & 3.12 & 3.10 & 3.06 & 2.92 & 2.96 \\
\hline Khmelnitsy & 0.00133 & 0.00154 & 0.00170 & 0.00171 & 0.00212 & 0.00059 & 3.19 & 3.14 & 3.34 & 3.23 & 3.25 & 3.10 \\
\hline Zhytomyr & 0.00133 & 0.00160 & 0.00170 & 0.00179 & 0.00213 & 0.00065 & 3.19 & 3.28 & 3.34 & 3.38 & 3.28 & 3.40 \\
\hline Vinnitsa & 0.00135 & 0.00162 & 0.00172 & 0.00187 & 0.00221 & 0.00066 & 3.23 & 3.31 & 3.36 & 3.54 & 3.39 & 3.46 \\
\hline Kirovograd & 0.00136 & 0.00163 & 0.00174 & 0.00188 & 0.00226 & 0.00066 & 3.25 & 3.34 & 3.41 & 3.55 & 3.47 & 3.49 \\
\hline Chernihiv & 0.00143 & 0.00169 & 0.00175 & 0.00190 & 0.00232 & 0.00067 & 3.42 & 3.45 & 3.44 & 3.60 & 3.56 & 3.50 \\
\hline Cherkassy & 0.00146 & 0.00177 & 0.00190 & 0.00193 & 0.00236 & 0.00068 & 3.49 & 3.63 & 3.73 & 3.64 & 3.63 & 3.58 \\
\hline Sumy & 0.00155 & 0.00189 & 0.00195 & 0.00203 & 0.00243 & 0.00070 & 3.72 & 3.88 & 3.83 & 3.83 & 3.74 & 3.69 \\
\hline Lviv & 0.00157 & 0.00194 & 0.00195 & 0.00206 & 0.00248 & 0.00071 & 3.77 & 3.96 & 3.83 & 3.88 & 3.80 & 3.75 \\
\hline Lugansk & 0.00158 & 0.00194 & 0.00198 & 0.00207 & 0.00253 & 0.00072 & 3.78 & 3.97 & 3.87 & 3.91 & 3.88 & 3.77 \\
\hline Nikolaev & 0.00174 & 0.00202 & 0.00198 & 0.00208 & 0.00253 & 0.00076 & 4.15 & 4.14 & 3.89 & 3.92 & 3.89 & 3.98 \\
\hline Odessa & 0.00185 & 0.00207 & 0.00217 & 0.00223 & 0.00256 & 0.00076 & 4.42 & 4.24 & 4.26 & 4.22 & 3.93 & 3.98 \\
\hline
\end{tabular}


Table A.1 (cont.). Output data for calculating the Gini coefficient based on local budget revenues without intergovernmental transfers in 2011-2016

\begin{tabular}{|l|l|l|l|l|l|l|l|l|l|l|l|l|}
\hline Kiev & 0.00190 & 0.00225 & 0.00235 & 0.00234 & 0.00289 & 0.00084 & 4.55 & 4.61 & 4.61 & 4.42 & 4.44 & 4.41 \\
\hline Kharkiv & 0.00214 & 0.00239 & 0.00250 & 0.00240 & 0.00290 & 0.00092 & 5.12 & 4.90 & 4.90 & 4.54 & 4.46 & 4.82 \\
\hline Poltava & 0.00222 & 0.00251 & 0.00264 & 0.00263 & 0.00318 & 0.00094 & 5.31 & 5.13 & 5.18 & 4.96 & 4.89 & 4.93 \\
\hline Donetsk & 0.00224 & 0.00264 & 0.00274 & 0.00269 & 0.00334 & 0.00103 & 5.35 & 5.40 & 5.37 & 5.08 & 5.13 & 5.40 \\
\hline Zaporozhye & 0.00228 & 0.00271 & 0.00286 & 0.00280 & 0.00355 & 0.00110 & 5.46 & 5.54 & 5.60 & 5.29 & 5.45 & 5.78 \\
\hline Dnipropetrovsk & 0.00254 & 0.00295 & 0.00307 & 0.00336 & 0.00404 & 0.00116 & 6.07 & 6.04 & 6.02 & 6.34 & 6.21 & 6.10 \\
\hline Kyiv & 0.00381 & 0.00438 & 0.00451 & 0.00515 & 0.00765 & 0.00219 & 9.11 & 8.96 & 8.85 & 9.73 & 11.76 & 11.52 \\
\hline Sum & 0.04178 & 0.04886 & 0.05099 & 0.05294 & 0.06508 & 0.01905 & & & & & & \\
\hline
\end{tabular}

Table A.2.

\begin{tabular}{|c|c|c|c|c|c|c|c|c|c|c|c|c|c|c|c|c|c|c|}
\hline \multirow[b]{2}{*}{ 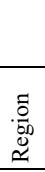 } & \multicolumn{6}{|c|}{$\begin{array}{l}\text { Cumulative share of distribution in terms of sign } \\
\text { values }\left(\text { Cum } y_{i}\right), \%\end{array}$} & \multicolumn{6}{|c|}{$x_{i}{ }^{*}$ Cum $y_{i}$} & \multicolumn{6}{|c|}{$x_{i}{ }^{*} y_{i}$} \\
\hline & $\overrightarrow{\mathrm{N}}$ & $\stackrel{\text { กิ }}{\tilde{1}}$ & $\stackrel{\text { ma }}{\stackrel{4}{1}}$ & $\stackrel{+}{\stackrel{4}{n}}$ & $\stackrel{n}{\stackrel{\sim}{*}}$ & 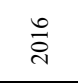 & $\overrightarrow{\vec{\sim}}$ & $\stackrel{\sim}{\stackrel{N}{\pi}}$ & $\stackrel{m}{\stackrel{n}{i}}$ & $\stackrel{+}{\stackrel{4}{n}}$ & $\stackrel{n}{\stackrel{n}{n}}$ & 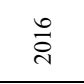 & $\overrightarrow{\vec{\sim}}$ & $\stackrel{4}{\tilde{2}}$ & $\stackrel{m}{i}$ & $\stackrel{+}{\stackrel{4}{*}}$ & $\stackrel{n}{\stackrel{n}{n}}$ & $\stackrel{\sim}{\stackrel{\sim}{*}}$ \\
\hline 1 & 2.31 & 2.24 & 2.28 & 2.37 & 1.50 & 1.33 & 9.24 & 8.95 & 9.13 & 9.49 & 6.01 & 5.31 & 9.24 & 8.95 & 9.13 & 9.49 & 6.01 & 5.31 \\
\hline 2 & 4.69 & 4.64 & 4.76 & 4. & 4.03 & 71 & 18.75 & 18.55 & 19.05 & 19.39 & .12 & .86 & 9.50 & 9.60 & 9.92 & 9.90 & 0.11 & .54 \\
\hline 3 & 7.41 & 7.27 & 7.50 & 7.43 & 6.57 & 6.17 & 29.64 & 29.07 & 30.00 & 29.73 & 26.30 & 24.67 & 10.90 & 10.52 & 10.95 & 10.35 & 10.18 & 9.82 \\
\hline 4 & 10.19 & 10.03 & 10.24 & 10.20 & 9.25 & 8.88 & 40.78 & 40.10 & 40.95 & 40.81 & 7.01 & 35.54 & 11.14 & 11.03 & 10.95 & 11.08 & 10.71 & 10.86 \\
\hline 5 & 13.18 & 12.88 & 13.01 & 13.00 & 12.05 & 11.62 & 52.73 & 51.52 & 52.06 & 52.02 & 48.20 & 46.46 & 11.96 & 11.42 & 11.10 & 11.20 & 11.19 & 10.92 \\
\hline 6 & 16.29 & 15.96 & 16.04 & 15.89 & 14.91 & 14.39 & 65.14 & 63.85 & 64.18 & 63.55 & 59.63 & 57.57 & 12.41 & 12.33 & 12.12 & 11.53 & 11.43 & 11.10 \\
\hline 7 & 19.41 & 19.08 & 19.15 & 18.94 & 17.83 & 17.35 & 77.63 & 76.33 & 76.58 & 75.77 & 71.31 & 69.39 & 12.49 & 12.47 & 12.40 & 12.22 & 11.69 & 11.82 \\
\hline 8 & 22.59 & 22.23 & 22.48 & 22.17 & 21.08 & 20.44 & 90.37 & 88.91 & 89.92 & 88.67 & 84.33 & 81.77 & 12.74 & 2.58 & 13.34 & 12.90 & 13.02 & 12.38 \\
\hline 9 & 25.79 & 25.51 & 25.82 & 25.55 & 24.36 & 23.84 & 103.14 & 102.05 & 103.28 & 102.20 & 97.45 & 95.38 & 12.77 & 13.14 & 13.36 & 13.53 & 13.12 & 13.61 \\
\hline 10 & 29.02 & 28.82 & 29.19 & 29.09 & 27.76 & 27.30 & 116.08 & 115.29 & 116.74 & 116.35 & 111.02 & 109.21 & 12.94 & 13.24 & 13.46 & 4.15 & 13.58 & 13.83 \\
\hline 11 & 32.27 & 32.16 & 32.60 & 32.64 & 31.23 & 30.79 & 129.08 & 128.63 & 130.40 & 130.54 & 124.92 & 123.16 & 13.00 & 13.34 & 13.66 & 14.19 & 13.89 & 13.95 \\
\hline 12 & 35.69 & 35.61 & 36.04 & 36.23 & 34.79 & 34.29 & 142.77 & 142.45 & 144.16 & 144.93 & 139.16 & 137.17 & 13.69 & 13.81 & 13.76 & 14.39 & 14.24 & 14.01 \\
\hline 13 & 39.18 & 39.24 & 39.77 & 39.87 & 38.42 & 37.87 & 156.73 & 156.95 & 159.08 & 159.49 & 153.66 & 151.49 & 13.96 & 14.51 & 14.92 & 14.56 & 14.50 & 14.32 \\
\hline 14 & 42.90 & 43.12 & 43.60 & 43.71 & 42.15 & 41.56 & 171.60 & 172.47 & 174.41 & 174.83 & 168.60 & 166.25 & 14.87 & 15.51 & 15.32 & 15.34 & 14.94 & 14.76 \\
\hline 15 & 46.67 & 47.08 & 47.44 & 47.59 & 45.95 & 45.31 & 186.67 & 188.32 & 189.74 & 190.36 & 183.82 & 181.25 & 15.08 & 15.85 & 15.34 & 15.54 & 15.22 & 15.00 \\
\hline 16 & 50.45 & 51.05 & 51.31 & 51.50 & 49.84 & 49.08 & 201.78 & 204.19 & 205.24 & 206.01 & 199.36 & 196.33 & 15.11 & 15.87 & 15.50 & 15.65 & 15.54 & 15.08 \\
\hline 17 & 54.60 & 55.19 & 55.20 & 55.42 & 53.73 & 53.06 & 218.40 & 220.76 & 220.79 & 221.69 & 214.93 & 212.25 & 16.61 & 16.57 & 15.55 & 15.68 & 15.58 & 15.92 \\
\hline 18 & 59.02 & 59.43 & 59.46 & 59.64 & 57.67 & 57.05 & 236.08 & 237.74 & 237.85 & 238.57 & 230.67 & 228.19 & 17.69 & 16.98 & 17.06 & 16.88 & 15.73 & 15.93 \\
\hline 19 & 63.57 & 64.04 & 64.07 & 64.06 & 62.11 & 61.46 & 254.30 & 256.17 & 256.28 & 256.25 & 248.42 & 245.84 & 18.21 & 18.43 & 18.43 & 17.68 & 17.76 & 17.66 \\
\hline 20 & 68.69 & 68.94 & 68.97 & 68.60 & 66.56 & 66.28 & 274.78 & 275.75 & 275.90 & 274.40 & 266.24 & 265.11 & 20.48 & 19.58 & 19.61 & 18.15 & 17.82 & 19.27 \\
\hline 21 & 74.01 & 74.07 & 74.16 & 73.56 & 71.45 & 71.21 & 296.02 & 296.26 & 296.63 & 294.24 & 285.81 & 284.83 & 21.25 & 20.51 & 20.74 & 19.84 & 19.57 & 19.72 \\
\hline 22 & 79.36 & 79.47 & 79.52 & 78.64 & 76.58 & 76.61 & 317.42 & 317.88 & 318.10 & 314.58 & 306.31 & 306.42 & 21.40 & 21.61 & 21.46 & 20.33 & 20.51 & 21.60 \\
\hline 23 & 84.82 & 85.01 & 85.13 & 83.93 & 82.03 & 82.39 & 339.26 & 340.03 & 340.51 & 335.72 & 328.13 & 329.54 & 21.84 & 22.15 & 22.41 & 21.14 & 21.81 & 23.12 \\
\hline 24 & 90.89 & 91.04 & 91.15 & 90.27 & 88.24 & 88.48 & 363.56 & 364.18 & 364.60 & 361.10 & 352.97 & 353.93 & 24.29 & 24.15 & 24.10 & 25.38 & 24.85 & 24.39 \\
\hline 25 & 100.00 & 100.00 & 100.00 & 100.00 & 100.00 & 100.00 & 400.00 & 400.00 & 400.00 & 400.00 & 400.00 & 400.00 & 36.44 & 35.82 & 35.40 & 38.90 & 47.03 & 46.07 \\
\hline$n$ & & & & & & & 4291.95 & 4296.39 & 4315.58 & 4300.70 & 4160.37 & 4121.93 & 400.00 & 400.00 & 400.00 & 400.00 & 400.00 & 400.00 \\
\hline
\end{tabular}

Notes: 1 -Ternopil; 2 - Zakarpattya; 3 - Chernivtsi; 4 - Volyn; 5- Kherson; 6 - Ivano-Frankivsk; 7 - Rivne; 8 - Khmelnitsy; 9-Zhytomyr; 10 - Vinnitsa; 11 - Kirovograd; 12 - Chernihiv; 13 - Cherkassy; 14 Sumy; 15 - Lviv; 16 - Lugansk; 17 - Nikolaev; 18 - Odessa; 19 - Kiev; 20 - Kharkiv; 21 Poltava; 22- Donetsk; 23 - Zaporozhye; 24 - Dnipropetrovsk; 25 - Kyiv.

\section{Appendix B}

Table B.1. Output data for calculating the Gini coefficient based on local budget revenues, considering intergovernmental transfers

\begin{tabular}{|c|c|c|c|c|c|c|c|c|c|c|c|c|}
\hline \multirow[t]{2}{*}{ The region } & \multicolumn{6}{|c|}{ MB revenues per capita, excluding intergovernmental transfers, UAH mln. } & \multicolumn{6}{|c|}{ The share of distribution by the value of the attribute $\left(y_{i}\right), \%$} \\
\hline & 2011 & 2012 & 2013 & 2014 & 2015 & 2016 & 2011 & 2012 & 2013 & 2014 & 2015 & 2016 \\
\hline Ternopil & 0.00351 & 0.00438 & 0.00404 & 0.00343 & 0.00245 & 0.00058 & 3.58 & 3.63 & 3.32 & 2.55 & 1.41 & 1.21 \\
\hline Zakarpattya & 0.00358 & 0.00438 & 0.00441 & 0.00419 & 0.00388 & 0.00095 & 3.65 & 3.63 & 3.62 & 3.12 & 2.22 & 1.99 \\
\hline Chernivtsi & 0.00365 & 0.00443 & 0.00459 & 0.00511 & 0.00659 & 0.00171 & 3.72 & 3.67 & 3.77 & 3.81 & 3.78 & 3.59 \\
\hline Volyn & 0.00368 & 0.00445 & 0.00463 & 0.00514 & 0.00670 & 0.00178 & 3.75 & 3.68 & 3.80 & 3.83 & 3.84 & 3.75 \\
\hline Kherson & 0.00369 & 0.00447 & 0.00464 & 0.00517 & 0.00670 & 0.00180 & 3.76 & 3.70 & 3.81 & 3.85 & 3.85 & 3.79 \\
\hline $\begin{array}{l}\text { Ivano- } \\
\text { Frankivsk }\end{array}$ & 0.00370 & 0.00450 & 0.00471 & 0.00518 & 0.00677 & 0.00181 & 3.77 & 3.73 & 3.86 & 3.86 & 3.88 & 3.80 \\
\hline
\end{tabular}


Table B.1 (cont.). Output data for calculating the Gini coefficient based on local budget revenues, considering intergovernmental transfers

\begin{tabular}{|c|c|c|c|c|c|c|c|c|c|c|c|c|}
\hline Rivne & 0.00371 & 0.00453 & 0.00471 & 0.00519 & 0.00677 & 0.00182 & 3.78 & 3.75 & 3.86 & 3.87 & 3.88 & 3.82 \\
\hline Khmelnitsy & 0.00372 & 0.00459 & 0.00473 & 0.00520 & 0.00685 & 0.00185 & 3.79 & 3.79 & 3.88 & 3.87 & 3.93 & 3.88 \\
\hline Zhytomyr & 0.00374 & 0.00462 & 0.00474 & 0.00524 & 0.00690 & 0.00186 & 3.82 & 3.83 & 3.89 & 3.90 & 3.96 & 3.90 \\
\hline Vinnitsa & 0.00378 & 0.00464 & 0.00475 & 0.00524 & 0.00696 & 0.00190 & 3.85 & 3.84 & 3.90 & 3.91 & 3.99 & 3.98 \\
\hline Kirovograd & 0.00383 & 0.00464 & 0.00475 & 0.00525 & 0.00701 & 0.00190 & 3.91 & 3.84 & 3.90 & 3.91 & 4.02 & 3.99 \\
\hline Chernihiv & 0.00385 & 0.00466 & 0.00480 & 0.00529 & 0.00703 & 0.00191 & 3.92 & 3.86 & 3.94 & 3.94 & 4.03 & 4.01 \\
\hline Cherkassy & 0.00390 & 0.00467 & 0.00481 & 0.00530 & 0.00708 & 0.00191 & 3.98 & 3.86 & 3.95 & 3.95 & 4.06 & 4.02 \\
\hline Sumy & 0.00393 & 0.00469 & 0.00484 & 0.00530 & 0.00713 & 0.00193 & 4.01 & 3.88 & 3.98 & 3.95 & 4.09 & 4.05 \\
\hline Lviv & 0.00393 & 0.00476 & 0.00486 & 0.00531 & 0.00713 & 0.00193 & 4.01 & 3.94 & 3.99 & 3.96 & 4.09 & 4.05 \\
\hline Lugansk & 0.00393 & 0.00477 & 0.00497 & 0.00538 & 0.00713 & 0.00194 & 4.01 & 3.94 & 4.08 & 4.01 & 4.09 & 4.08 \\
\hline Nikolaev & 0.00394 & 0.00485 & 0.00498 & 0.00544 & 0.00721 & 0.00197 & 4.02 & 4.02 & 4.09 & 4.05 & 4.13 & 4.13 \\
\hline Odessa & 0.00397 & 0.00488 & 0.00500 & 0.00546 & 0.00722 & 0.00200 & 4.05 & 4.04 & 4.11 & 4.07 & 4.14 & 4.20 \\
\hline Kiev & 0.00397 & 0.00496 & 0.00501 & 0.00547 & 0.00728 & 0.00202 & 4.05 & 4.10 & 4.11 & 4.07 & 4.17 & 4.24 \\
\hline Kharkiv & 0.00401 & 0.00509 & 0.00501 & 0.00548 & 0.00739 & 0.00209 & 4.09 & 4.21 & 4.11 & 4.08 & 4.24 & 4.39 \\
\hline Poltava & 0.00403 & 0.00509 & 0.00512 & 0.00562 & 0.00762 & 0.00213 & 4.11 & 4.21 & 4.21 & 4.18 & 4.37 & 4.47 \\
\hline Donetsk & 0.00418 & 0.00510 & 0.00517 & 0.00566 & 0.00767 & 0.00214 & 4.26 & 4.22 & 4.25 & 4.21 & 4.40 & 4.50 \\
\hline Zaporozhye & 0.00433 & 0.00511 & 0.00535 & 0.00593 & 0.00786 & 0.00238 & 4.41 & 4.23 & 4.39 & 4.42 & 4.51 & 4.99 \\
\hline Dnipropetrovsk & 0.00435 & 0.00513 & 0.00541 & 0.00604 & 0.00808 & 0.00241 & 4.43 & 4.25 & 4.44 & 4.50 & 4.63 & 5.05 \\
\hline Kyiv & 0.00518 & 0.00747 & 0.00578 & 0.00827 & 0.01092 & 0.00292 & 5.29 & 6.18 & 4.74 & 6.16 & 6.27 & 6.13 \\
\hline Sum & 0.09809 & & 0.12182 & 0.13426 & 0.17432 & 0.04762 & & & & & & \\
\hline
\end{tabular}

Table B.2.

\begin{tabular}{|c|c|c|c|c|c|c|c|c|c|c|c|c|c|c|c|c|c|c|}
\hline \multirow[b]{2}{*}{ Б } & \multicolumn{6}{|c|}{$\begin{array}{l}\text { Cumulative share of distribution in terms of } \\
\left.\text { sign values (Cum } y_{i}\right), \%\end{array}$} & \multicolumn{6}{|c|}{$x_{i}{ }^{*}$ Cum $y_{i}$} & \multicolumn{6}{|c|}{$x_{i}{ }^{*} y_{i}$} \\
\hline & $\overrightarrow{\vec{\sim}}$ & $\stackrel{\text { Iิ }}{\mathrm{i}}$ & $\stackrel{m}{\stackrel{n}{\sim}}$ & $\stackrel{+}{\stackrel{i}{i}}$ & $\stackrel{n}{\stackrel{n}{\sim}}$ & $\stackrel{\sim}{\stackrel{0}{\sim}}$ & $\overrightarrow{\vec{\sim}}$ & $\stackrel{\sim}{\stackrel{ก}{े}}$ & $\stackrel{m}{\stackrel{i}{i}}$ & 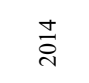 & $\stackrel{n}{\stackrel{n}{i}}$ & $\stackrel{\overbrace{}}{\stackrel{\circ}{i}}$ & $\overline{\bar{i}}$ & $\stackrel{\sim}{\stackrel{\sim}{े}}$ & $\stackrel{m}{\stackrel{i}{i}}$ & $\stackrel{+}{\stackrel{i}{i}}$ & $\stackrel{n}{\stackrel{n}{i}}$ & $\stackrel{\overbrace{}}{\stackrel{\circ}{*}}$ \\
\hline 1 & 3.58 & 3.63 & 3.32 & 2.55 & 1.41 & 1.21 & 14.33 & 14.50 & 13.27 & 10.21 & 5.63 & 4.84 & 14.33 & 14.50 & 13.27 & 10.21 & 5.63 & 4.84 \\
\hline 2 & 7.23 & 7.25 & 6.93 & 5.67 & 3.63 & 3.20 & 28.91 & 29.01 & 27.73 & 22.68 & 14.52 & 12.81 & 14.58 & 14.51 & 14.47 & 12.48 & 8.89 & 7.97 \\
\hline 3 & 10.94 & 10.92 & 10.70 & 9.48 & 7.41 & 6.80 & 43.78 & 43.67 & 42.81 & 37.90 & 29.64 & 27.18 & 14.87 & 14.66 & 15.07 & 15.22 & 15.12 & 14.37 \\
\hline 4 & 14.69 & 14.60 & 14.50 & 13.31 & 11.25 & 10.54 & 58.77 & 58.39 & 58.01 & 53.22 & 45.01 & 42.16 & 14.99 & 14.71 & 15.21 & 15.32 & 15.37 & 14.98 \\
\hline 5 & 18.46 & 18.30 & 18.31 & 17.15 & 15.10 & 14.33 & 73.82 & 73.20 & 73.26 & 68.61 & 60.39 & 57.31 & 15.05 & 14.81 & 15.24 & 15.39 & 15.38 & 15.14 \\
\hline 6 & 22.22 & 22.03 & 22.18 & 21.01 & 18.98 & 18.13 & 88.89 & 88.10 & 88.70 & 84.04 & 75.92 & 72.52 & 15.07 & 14.91 & 15.45 & 15.43 & 15.53 & 15.21 \\
\hline 7 & 26.00 & 25.77 & 26.04 & 24.88 & 22.86 & 21.95 & 104.02 & 103.09 & 104.16 & 99.50 & 91.46 & 87.81 & 15.12 & 14.99 & 15.46 & 15.46 & 15.54 & 15.29 \\
\hline 8 & 29.80 & 29.57 & 29.92 & 28.75 & 26.79 & 25.83 & 119.19 & 118.27 & 119.70 & 114.98 & 107.18 & 103.34 & 15.18 & 15.18 & 15.54 & 15.48 & 15.72 & 15.53 \\
\hline 9 & 33.61 & 33.39 & 33.82 & 32.65 & 30.75 & 29.73 & 134.45 & 133.57 & 135.27 & 130.58 & 123.00 & 118.93 & 15.26 & 15.30 & 15.57 & 15.60 & 15.83 & 15.59 \\
\hline 10 & 37.47 & 37.23 & 37.72 & 36.55 & 34.74 & 33.71 & 149.87 & 148.91 & 150.86 & 146.20 & 138.97 & 134.84 & 15.42 & 15.35 & 15.59 & 15.62 & 15.97 & 15.92 \\
\hline 11 & 41.37 & 41.07 & 41.61 & 40.46 & 38.77 & 37.70 & 165.50 & 164.26 & 166.46 & 161.84 & 155.07 & 150.80 & 15.63 & 15.35 & 15.60 & 15.63 & 16.10 & 15.95 \\
\hline 12 & 45.29 & 44.92 & 45.56 & 44.40 & 42.80 & 41.71 & 181.18 & 179.68 & 182.23 & 177.59 & 171.21 & 166.82 & 15.68 & 15.42 & 15.77 & 15.75 & 16.14 & 16.02 \\
\hline 13 & 49.27 & 48.78 & 49.51 & 48.34 & 46.86 & 45.72 & 197.09 & 195.14 & 198.03 & 193.37 & 187.45 & 182.89 & 15.92 & 15.45 & 15.81 & 15.78 & 16.24 & 16.07 \\
\hline 14 & 53.28 & 52.66 & 53.48 & 52.29 & 50.95 & 49.77 & 213.12 & 210.66 & 213.94 & 209.16 & 203.80 & 199.08 & 16.02 & 15.52 & 15.90 & 15.79 & 16.35 & 16.19 \\
\hline 15 & 57.29 & 56.61 & 57.48 & 56.25 & 55.04 & 53.82 & 229.14 & 226.43 & 229.91 & 224.99 & 220.17 & 215.28 & 16.03 & 15.77 & 15.97 & 15.83 & 16.37 & 16.20 \\
\hline 16 & 61.30 & 60.55 & 61.56 & 60.26 & 59.14 & 57.90 & 245.19 & 242.20 & 246.23 & 241.03 & 236.54 & 231.58 & 16.04 & 15.78 & 16.32 & 16.04 & 16.37 & 16.31 \\
\hline 17 & 65.31 & 64.57 & 65.64 & 64.31 & 63.27 & 62.03 & 261.26 & 258.27 & 262.58 & 257.25 & 253.08 & 248.11 & 16.07 & 16.06 & 16.35 & 16.22 & 16.54 & 16.52 \\
\hline 18 & 69.36 & 68.60 & 69.75 & 68.38 & 67.41 & 66.23 & 277.44 & 274.41 & 279.00 & 273.52 & 269.64 & 264.93 & 16.19 & 16.15 & 16.42 & 16.27 & 16.56 & 16.82 \\
\hline 19 & 73.41 & 72.70 & 73.86 & 72.45 & 71.58 & 70.47 & 293.64 & 290.82 & 295.45 & 289.81 & 286.34 & 281.88 & 16.19 & 16.40 & 16.45 & 16.29 & 16.69 & 16.96 \\
\hline 20 & 77.50 & 76.91 & 77.98 & 76.53 & 75.82 & 74.86 & 309.99 & 307.65 & 311.91 & 306.14 & 303.28 & 299.44 & 16.36 & 16.83 & 16.45 & 16.33 & 16.95 & 17.56 \\
\hline 21 & 81.61 & 81.12 & 82.18 & 80.72 & 80.19 & 79.33 & 326.44 & 324.50 & 328.73 & 322.87 & 320.77 & 317.33 & 16.44 & 16.85 & 16.82 & 16.74 & 17.48 & 17.89 \\
\hline 22 & 85.87 & 85.35 & 86.43 & 84.93 & 84.59 & 83.83 & 343.47 & 341.39 & 345.71 & 339.72 & 338.36 & 335.32 & 17.03 & 16.89 & 16.98 & 16.85 & 17.60 & 17.99 \\
\hline 23 & 90.28 & 89.57 & 90.82 & 89.35 & 89.10 & 88.82 & 361.12 & 358.29 & 363.26 & 357.39 & 356.41 & 355.29 & 17.65 & 16.90 & 17.55 & 17.66 & 18.05 & 19.96 \\
\hline 24 & 94.71 & 93.82 & 95.26 & 93.84 & 93.73 & 93.87 & 378.86 & 375.29 & 381.02 & 375.37 & 374.94 & 375.49 & 17.74 & 16.99 & 17.76 & 17.98 & 18.53 & 20.20 \\
\hline 25 & 100.00 & 100.00 & 100.00 & 100.00 & 100.00 & 100.00 & 400.00 & 400.00 & 400.00 & 400.00 & 400.00 & 400.00 & 21.14 & 24.71 & 18.98 & 24.63 & 25.06 & 24.51 \\
\hline$\underline{\Xi}$ & & & & & & & 4999.47 & 4959.69 & 5018.23 & 4898.01 & 4768.76 & 4685.98 & 400.00 & 400.0 & 400.00 & 400.0 & 400.00 & 400.00 \\
\hline
\end{tabular}

Notes: 1 -Ternopil; 2 - Zakarpattya; 3 - Chernivtsi; 4 - Volyn; 5- Kherson; 6 - Ivano-Frankivsk; 7 - Rivne; 8 - Khmelnitsy; 9-Zhytomyr; 10 - Vinnitsa 11 - Kirovograd; 12 - Chernihiv; 13 - Cherkassy; 14 Sumy; 15 - Lviv; 16 - Lugansk; 17 - Nikolaev; 18 - Odessa; 19 - Kiev; 20 - Kharkiv; 21 Poltava; 22- Donetsk; 23 - Zaporozhye; 24 - Dnipropetrovsk; 25 - Kyiv. 